Results This SLR retrieved 8,631 unique references of which a total of 50 references were accepted and extracted in this SLR (figure 1).

The 50 references identified covered 18 clinical trials that evaluated maintenance therapies in OC patients following one prior line of chemotherapy. Of these 18 trials, 12 were RCTs and the remaining 6 were observational, dose escalation and retrospective review studies.

Of the 18 trials, only 2 did not assess PFS as an efficacy endpoint (NCT00058435 and MIMOSA). PARP inhibitors across the board reported a better PFS hazard ratio (HR) than other OC maintenance therapies (table 1). No pattern was identified in relation to PFS amongst patients who were treated with a maintenance therapy following first-line platinum-based chemotherapy versus those who received a

Abstract 373 Table 1 PFS and OS studies included in the
analysis

\begin{tabular}{|c|c|c|c|}
\hline Trial & Drug(s) & PFS, HR (95\% Cl) & OS, HR $(95 \% \mathrm{Cl})$ \\
\hline \begin{tabular}{|c|} 
NCT00058435 \\
Sabbatini 2006 \\
\end{tabular} & Abagovomab & NA & NA \\
\hline $\begin{array}{l}\text { MIMOSA } \\
\text { (NCT00418574) } \\
\text { Sabbatini 2013 }\end{array}$ & $\begin{array}{l}\text { Arm 1: Abagovomab } \\
\text { Arm 2: Placebo }\end{array}$ & $1.099(0.919-1.315)^{*}$ & $\begin{array}{l}1.15(0.872- \\
1.1518)\end{array}$ \\
\hline $\begin{array}{l}\text { ICON-7 } \\
\text { (NCT00483782) } \\
\text { Oza 2015 }\end{array}$ & $\begin{array}{l}\text { Arm 1: Chemotherapy + } \\
\text { surveillance } \\
\text { Arm 2: Chemotherapy + } \\
\text { Bevacizumab }\end{array}$ & $0.93(0.83-1.05)$ & $0.99(0.85-1.14)$ \\
\hline \begin{tabular}{|c|} 
AGO-OVAR16 \\
(NCT00866697) \\
Du Bois 2014 \\
\end{tabular} & $\begin{array}{l}\text { Arm 1: Pazopanib } \\
\text { Arm 2: Placebo }\end{array}$ & $0.766(0.643-0.911)$ & $\begin{array}{l}0.96(0.805- \\
1.145)^{\dagger}\end{array}$ \\
\hline \begin{tabular}{|l} 
SOLO-1 \\
(NCT01844986) \\
Moore 2018 \\
\end{tabular} & $\begin{array}{l}\text { Arm 1: Olaparib } \\
\text { Arm 2: Placebo }\end{array}$ & $0.30(0.23-0.41)$ & $0.95(0.60-1.53)$ \\
\hline \begin{tabular}{|l|} 
Knipprath-Meszaros \\
2017 \\
\end{tabular} & $\begin{array}{l}\text { Arm 1: Letrozole } \\
\text { Arm 2: "Do Nothing" }\end{array}$ & NR & NA \\
\hline Goel 2017 & $\begin{array}{l}\text { Arm 1: Tamoxifen } \\
\text { Arm 2: Treatment } \\
\text { Surveillance }\end{array}$ & NR & NA \\
\hline \begin{tabular}{|l|} 
AGO-OVAR16 \\
(NCT00866697); \\
NCT01227928 (East \\
Asian sub study) \\
Kim 2018
\end{tabular} & $\begin{array}{l}\text { Arm 1: Pazopanib } \\
\text { Arm 2: Placebo }\end{array}$ & $1.114(0.818-1.518)$ & NR \\
\hline \begin{tabular}{|c|} 
NCT01227928 \\
Zang 2013 \\
\end{tabular} & $\begin{array}{l}\text { Arm 1: Pazopanib } \\
\text { Arm 2: Placebo }\end{array}$ & $0.98(0.593-1.620)$ & NA \\
\hline \begin{tabular}{|l} 
JGOG3022 \\
(NCT00951496) \\
Komiyama 2019 \\
\end{tabular} & $\begin{array}{l}\text { Arm 1: Chemotherapy + } \\
\text { Bevacizumab }\end{array}$ & NR & NA \\
\hline $\begin{array}{l}\text { OSCAR } \\
\text { (NCT01863693) } \\
\text { Hall 2018 }\end{array}$ & $\begin{array}{l}\text { Arm 1: Chemotherapy + } \\
\text { Bevacizumab + } \\
\text { Bevacizumab } \\
\text { maintenance }\end{array}$ & NR & NA \\
\hline $\begin{array}{l}\text { PAOLA-1 } \\
\text { (NCT02477644) } \\
\text { Ray-Coquard 2019 }\end{array}$ & $\begin{array}{l}\text { Arm 1: Olaparib + } \\
\text { Bevacizumab } \\
\text { Arm 2: Placebo + } \\
\text { Bevacizumab }\end{array}$ & $0.59(0.49-0.72)$ & NR \\
\hline $\begin{array}{l}\text { PRIMA } \\
\text { (NCT02655015) } \\
\text { Gonzalez-Martin } 2019\end{array}$ & $\begin{array}{l}\text { Arm 1: Niraparib } \\
\text { Arm 2: Placebo }\end{array}$ & $0.62(0.5-0.76)$ & $0.7(0.44-1.11)$ \\
\hline $\begin{array}{l}\text { CHIVA/GINECO } \\
\text { (NCT01583322) } \\
\text { Feron 2019 }\end{array}$ & \begin{tabular}{|l|} 
Arm 1: NACT + \\
Nintendanib + \\
Nintendanib \\
maintenance \\
Arm 2: NACT + Placebo \\
+ Placebo maintenance \\
\end{tabular} & 1.5 & 1.54 \\
\hline $\begin{array}{l}\text { ESME (NCT03275298) } \\
\text { Romeo } 2019\end{array}$ & $\begin{array}{l}\text { Arm 1: Platinum-based } \\
\text { Chemotherapy + } \\
\text { maintenance }\end{array}$ & NR & NR \\
\hline \begin{tabular}{|l} 
TRINOVA-3 \\
(NCT01493505) \\
Vergote 2019
\end{tabular} & $\begin{array}{l}\text { Arm 1: Chemotherapy + } \\
\text { Trebananib + Trebananib } \\
\text { maintenance } \\
\text { Arm 2: Chemotherapy + } \\
\text { Placebo + Placebo } \\
\text { maintenance }\end{array}$ & $0.93(0.79-1.09)$ & $0.99(0.79-1.25)$ \\
\hline $\begin{array}{l}\text { VELIA/GOG-3005 } \\
\text { (NCT02470585) } \\
\text { Coleman 2020 }\end{array}$ & $\begin{array}{l}\text { Arm 1: Chemotherapy + } \\
\text { Veliparib + Veliparib } \\
\text { maintenance } \\
\text { Arm 2: Chemotherapy + } \\
\text { Placebo + Placebo } \\
\text { maintenance }\end{array}$ & $0.68(0.56-0.83)$ & NR \\
\hline $\begin{array}{l}\text { AGO-OVAR12 } \\
\text { (NCT01015118) } \\
\text { Ray-Coquard 2017 }\end{array}$ & $\begin{array}{l}\text { Arm 1: Chemotherapy + } \\
\text { Nintendanib + } \\
\text { Nintendanib } \\
\text { maintenance } \\
\text { Arm 2: Chemotherapy + } \\
\text { Placebo + Placebo } \\
\text { maintenance }\end{array}$ & NR & $0.99(0.83-1.17)$ \\
\hline $\begin{array}{l}\text { GOG-0218 } \\
\text { (NCT00262847) } \\
\text { Burger 2011 }\end{array}$ & $\begin{array}{l}\text { Arm 1: Chemotherapy + } \\
\text { Bevacizumab + } \\
\text { Bevacizumab } \\
\text { maintenance } \\
\text { Arm 2: Chemotherapy + } \\
\text { Placebo + Placebo } \\
\text { maintenance }\end{array}$ & $0.77(0.681-0.870)$ & $0.915^{\ddagger}$ \\
\hline
\end{tabular}

maintenance drug concurrently with first-line platinum-based chemotherapy and then continued with the maintenance treatment.

OS was reported as a secondary endpoint in 12 trials (MIMOSA, AGO-OVAR16, SOLO-1, ICON-7, GOG-0218, AGO-OVAR12, VELIA/GOG-3005, TRINOVA-3, ESME, CHIVA/GINESCO, PRIMA and PAOLA-1). Only PARP inhibitor-containing therapies reported significant OS HRs below 1 across all trial populations.

TEAEs were reported for 11 of the 18 trials. Discontinuation due to AEs was reported in 10 of the 18 trials.

Conclusion Therapies that included PARP inhibitors reported better PFS HR than other OC maintenance therapies. In study populations including both BRCA mutation positive and wild type, clinical benefit is conferred by both olaparib plus bevacizumab and niraparib as indicated by PFS. OS data remain immature.

Disclosures This study was funded by GlaxoSmithKline.

Clinical Trial Registration: N/A

Dr Guy and Walder report institutional reimbursements from GlaxoSmithKline.

Drs. Travers, Hawkes, Malinowska, and Gupta are employees of GlaxoSmithKline.

\section{REAL WORLD PROGNOSTIC RELEVANCE OF RESIDUAL DISEASE AND OTHER CLINICAL FACTORS ON THE PROGRESSION OF DISEASE AND DEATH IN PATIENTS WITH ADVANCED OVARIAN CANCER IN THE US}

${ }^{1}$ Dana Chase, ${ }^{2}$ Jessica Perhanidis, ${ }^{2}$ Divya Gupta, ${ }^{3}$ Linda Kalilani, ${ }^{2}$ Leah Sansbury, ${ }^{2}$ Tatia Woodward, ${ }^{3}$ Antonio González-Martín. ${ }^{1}$ University of Arizona Cancer Center: ${ }^{2}$ Glaxosmithkline; ${ }^{3}$ Grupo Español de Investigación en Cáncer de Ovario (GEICO) and the Medical Oncology Department, Clínica Universidad de Navarra, Madrid, Spain

\subsection{6/ijgc-2020-ESGO.128}

Introduction/Background Although most patients with ovarian cancer (OC) respond to first line (1L) treatment, 70\% of women experience disease progression (PD) within 3 years. Identifying prognostic factors that impact survival is crucial to identify patients who may benefit from new treatment regimens such as maintenance therapies. The objective of this study was to assess the association between visible residual disease (VRD) following interval (IDS) or primary debulking surgery (PDS) and other clinical factors, and the risk of PD or death in patients with advanced OC in a real-world setting. Methodology This retrospective cohort study included patients diagnosed with invasive ovarian cancer between January 1, 2011 and February 29, 2020, from the Flatiron Health electronic health record-derived de-identified US database (most OC patients $(87 \%)$ originate from community oncology practices). Inclusion/exclusion criteria are shown in table 1 . The index date (ID) was defined as the last date of $1 \mathrm{~L}$ treatment. Multivariate Cox regression models were used to identify demographic and clinical factors associated with time to next

Abstract 374 Table 1 Inclusion/Exclusion criteria

\begin{tabular}{|l|l|}
\hline Inclusion criteria & Exclusion criteria \\
\hline Patients were $\geq 18$ years old & Missing an IDS or PDS date \\
\hline Stage III or IV disease & Had IDS or PDS and unknown VRD status \\
\hline Received any 1L treatment & \\
\hline $\begin{array}{l}\text { Had } \geq 12 \text { weeks of follow-up after completing 1L } \\
\text { treatment }\end{array}$ & \\
\hline
\end{tabular}


Abstract 374 Table 2 TTNT and OS results (unadjusted)

\begin{tabular}{|c|c|c|c|}
\hline & $\begin{array}{c}\text { Patients with VRD } \\
(\mathbf{N = 1 1 0 9 )}\end{array}$ & $\begin{array}{c}\text { Patients with no VRD } \\
(\mathbf{N = 8 1 1 )}\end{array}$ & $\begin{array}{c}\text { Overall } \\
(\mathbf{N}=1920)\end{array}$ \\
\hline Median TTNT $(95 \% \mathrm{Cl})$, months & $6.4(5.7-7.1)$ & $11.9(10.7-12.9)$ & $8.0(7.5-8.5)$ \\
\hline Hazard ratio $(90 \% \mathrm{Cl})$ & \multicolumn{2}{|c|}{$1.7(1.5-1.8)$} \\
\hline Median OS $(95 \% \mathrm{Cl})$, months & $28.6(26.0-31.2)$ & $54.5(48.5-65.3)$ & $36.6(34.5-38.9)$ \\
\hline Hazard ratio $(90 \% \mathrm{Cl})$ & \multicolumn{2}{|c|}{$2.1(1.9-2.4)$} & \\
\hline
\end{tabular}

TTNT=time to next treatment; OS=overall survival; VRD=visible residual disease.

treatment (TTNT,a proxy for PD), defined as time from ID to start date of second line treatment, death, or last confirmed structured activity. Overall survival (OS) was defined as time from ID to death or last confirmed structured activity. Kaplan Meier analysis was used to assess median TTNT and OS.

Results A total of 1,920 advanced OC patients with a median (25th, 75th percentile) age of $67.0(58.0,75.0)$ years were included. Most patients were white (74\%) and originated from a community oncology practice $(88 \%)$. While $67 \%$ of patients had evidence of a BRCA biomarker test, only 5\% had evidence of a homologous recombination deficient (HRD) test.

Results are shown in table 2. Statistically significant predictors of OS were VRD, age, BRCA status, Eastern Cooperative Oncology Group (ECOG) score, extent of debulking, histology, stage of disease, and therapy modality. Statistically significant predictors of TTNT included: VRD, BRCA status, extent of debulking, histology, practice type, race, stage of disease, and therapy modality.

Conclusion VRD was a key predictor of TTNT and mortality in patients with advanced OC. Among biomarkers, BRCA status was a key predictor of OC outcomes; HRD could not be assessed due to lack of data. A key strength of this study is that it presents outcomes from community practices primarily, whereas most retrospective studies contain a higher proportion of academic practices.

Disclosures Dr. Chase reports speakers' bureau fees from GSK.
Dr. González-Martín reports personal fees and non-financial support from AstraZeneca; Grant and personal fees from GSK, Clovis Oncology, Roche Holding AG, Merck \& Co., Inc., Genmab, INMUNOGEN, Pharma Mar, S.A., and Oncoinvent AS.

Drs. Kalilani, Perhanidis, Sansbury, Woodward and Gupta are employees of GlaxoSmithKline.

\section{REAL WORLD RETROSPECTIVE STUDY OF PATIENTS WITH EPITHELIAL OVARIAN CANCER: AN INTERNATIONAL COMPARISON}

${ }^{1}$ Sue Cheeseman, ${ }^{2}$ Bethany Levick, ${ }^{3}$ Eunji Nam, ${ }^{3}$ Subin Lim, ${ }^{4}$ Roman Rouzier, ${ }^{4}$ Claire Bonneau, ${ }^{5}$ Milan Paul Kubelac, ${ }^{6}$ Patriciu A Achimas-Cadariu, ${ }^{7}$ Jean Marc Classe, ${ }^{7}$ Francois Bocquet, ${ }^{8}$ Sven Becker, ${ }^{2}$ Mariana Guergova-Kuras, ${ }^{1}$ Geoff Hall. ${ }^{1}$ Leeds Cancer Centre; Leeds Teaching Hospitals NHS Trust; ${ }^{2}$ lqvia; ${ }^{3}$ Yonsei Severance; ${ }^{4}$ Institut Curie; ${ }^{5}$ The Oncology Institute 'Prof Dr lon Chiricuta'; ${ }^{6}$ lon Chiricuta Institute of Oncology; ${ }^{7}$ Institut de Cancerologie Ouest; ${ }^{8}$ Universitätsklinikum Frankfurt; Klinik für Gynäkologie und Geburtshilfe

\subsection{6/ijgc-2020-ESG0.129}

Introduction/Background Clinical trials in Epithelial Ovarian Cancer (EOC) frequently examine treatment at a particular phase of the patient's disease trajectory. Few major studies have examined the management of patients from diagnosis to death. This international network was developed to compare

Abstract 379 Table 1 Characteristics of ovarian cancer patients treated at 6 participating centres between 2012 and 2018

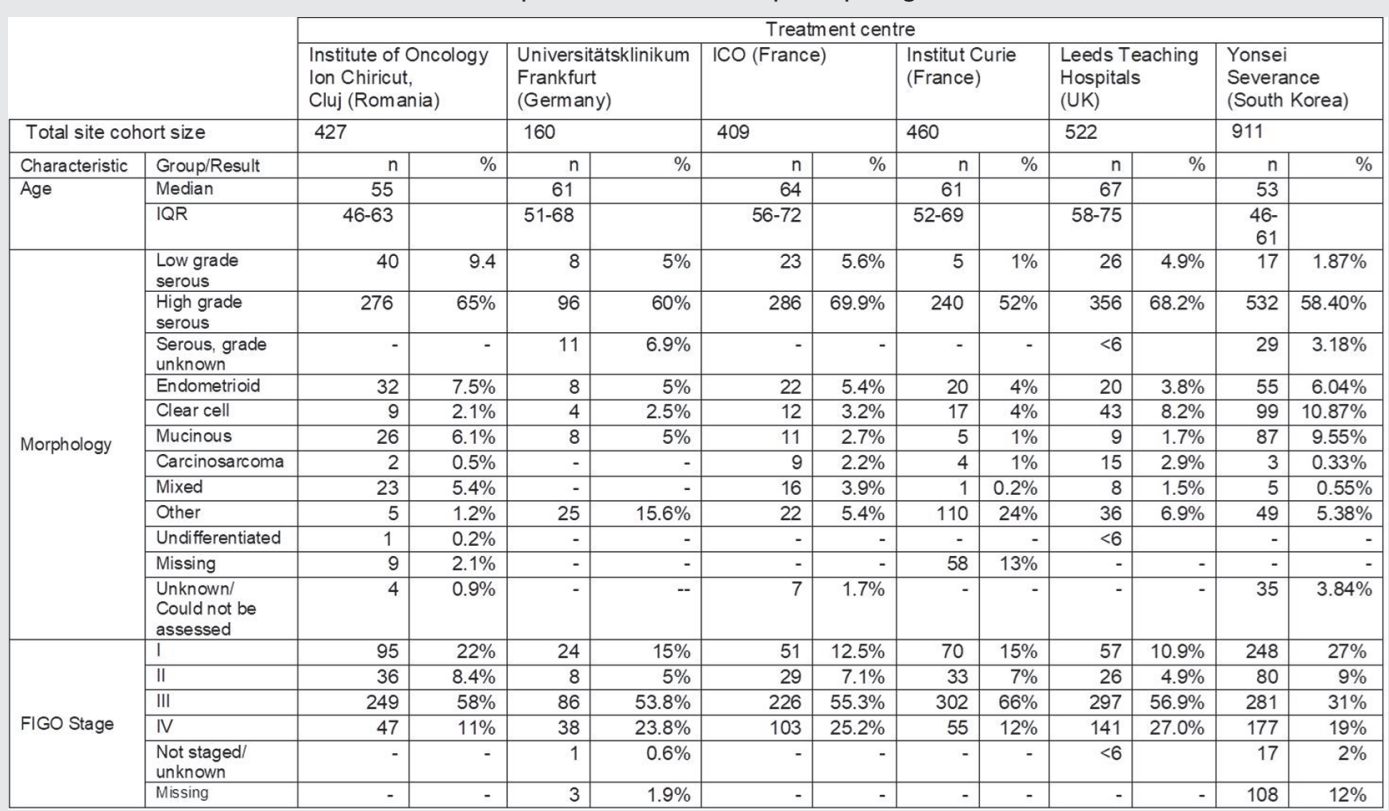

